\title{
SS-040 犯罪捜査のための虚偽検出研究一隠匿情報検査の「弁別的反応」 をめぐってー
}

\author{
企画代表者、話題提供者、司会者：藤原 修治（京都府警科学捜査研究所） \\ 企画者、司会者: 久保 賢太 (名古屋大学) \\ 話題提供者：財津 亘（富山県警科学捜査研究所） \\ 話題提供者: 渋谷 友祐 (鳥取県警科学捜査研究所) \\ 指定討論者 : 高澤 則美 (江戸川大学) \\ 指定討論者 : 手塚 洋介 (大阪体育大学)
}

現在, 全国の科学捜査研究所に扔いて隠匿情報検査 (Concealed Information test：CIT) によるポリ グラフ検査が実施されている。CITは弁別を原理とする一種の記憶検査であり, 実務場面では, 生理反 応に認められた弁別的反応の有無から被検查者の事件事実の認識の有無を推定することで, 事件解決に 貢献している。その一方で, 実務場面で認められる弁別的反応の規定因や検出法には, 取り組むべき課 題が残されている。

本シンポジウムでは, これらの課題を実務・基礎の双方から解決するきっかけとするため, 現在の研究 課題を整理し,すでに取り組まれている研究について紹介する。弁別的反応の規定因となる記憶の質(財 津) ・実務検査で認められる特徵（藤原）・デー夕分析における個人差の統制法（渋谷）といった研究の 成果を紹介し, 各研究の意義と今後の展望について議論する。 